\title{
Attitude toward using Fintech among Millennials
}

\author{
A Jiwasiddi ${ }^{1}$, C T Adhikara ${ }^{1}$, M R R Adam ${ }^{2}$ and I Triana ${ }^{1}$ \\ ${ }^{1}$ Management Department, BINUS Business School Undergraduate Program, Bina Nusantara \\ University, Jakarta, Indonesia \\ ${ }^{2}$ Management Department, Swiss German University, Jl. Jalur Sutera Barat Kav 15, Banten, \\ Indonesia \\ ctadhikara@binus.ac.id
}

\begin{abstract}
The rapid development of information and communications technology is transforming the entire industry landscape, which ultimately affects the convergence sector. Financial technology also known as Fintech refers to the technology-enabled financial solution. Fintech saw today as the combination of financial service and information technology. In recent years there is numerous research dedicated to Fintech. Fintech has been classified into several categories, some categories have significantly higher traffic than others. As this research is focused on the attitude toward using Fintech for Millenials, we are using the most relevant category which is money transfer and payments. This research was investigating the influence of Brand and service trust, perceived usefulness and perceived ease of use toward attitude toward using Fintech. Taking place in a university located in Jakarta, the result of this research confirm that indeed every factor used in this research, namely brand and service trust, perceived usefulness and perceived ease of use shows a significant impact to attitude towards using Fintech.
\end{abstract}

Keywords: Attitude, fintech, millennials

\section{INTRODUCTION}

In the era of digitalization, Financial Technology or often called "Fintech" has become one of the fastest growing topics in e-business. Fintech is generally understood as computer support and technology used in order to support or enable banking or other Financial services [1]. Fintech was categorized into several types of services, such as 1) Savings and investment 2) Money transfer \& Payment 3) Borrowing and 4) Insurance.

The highest number of uses was money transfer and payment, either its money transfer or online foreign exchange [1][2]. This shifting affects many another aspect of doing business and in user ways of consumption.

Millennials as one of the largest generations is soon going to enter their prime years, they will become a big part of the future world, both as the consumer and as workers. Millennials have held an important role as they will become a huge part that play an important role in shaping and building business and industries. The millennials are often attributed to "technology savvy generation", they are very familiar with the use of technology. The Millennials have specific traits which are called 3C's, which are Creative, Connected and Confidence [3].

Fintech and all of the advantages has become a big trend that's happening worldwide today, it is very interesting and also very important too to understand how the millennials perceived 
Financial Technology itself considering not only that they are massive in numbers but also held a strong role for the future.

The integration of technology has influence in almost every aspect of life, this includes the business and human aspect of it. Fintech has become indispensable topic and is the focus of new technology applications with great market potential. Fintech Service and ferments overnight, subverts the oppressive global domain of service industries [2].

Fintech is a service sector which uses mobile-centered IT technology to enhance the efficiency of the financial system. As a term, it is a compound of "finance" and "technology", and collectively refers to industrial changes forged from the convergence of financial services and IT. Fintech was considered as It is an innovative service which provides differentiated financial services using new technologies, such as mobile, social media, and IoT (Internet of Things). A recent example is the mobile-based payment and settlement system, which is the most representative service of its kind in Korea. In terms of industry, it refers to the phenomenon where a non-financial business uses innovative technology to provide services, such as remittance, payment and settlement, and investment, without working with a financial company. Major examples are Apple Pay and Ali Pay [4], others state economic industry composed of companies that use technology to make financial services more efficient [1][5].

Gulamhuseinwala, Bull \& Lewis (2015) [1] stated that Non-bank money transfers have become extremely common among digitally active consumers - they are a mainstream product. We have adjusted for this over-indexing by categorizing as FinTech adopters those who say that they have used two or more of the 10 products listed in Table 1. in the last six months. Which indicates that there are a very strong tendency on using Fintech, not only that consumer getting more educated and comfortable in using several types of fintech for their needs

Table 1. Categories of Financial Technology

\begin{tabular}{|c|c|c|c|}
\hline Savings and Investments & $\begin{array}{l}\text { Money transfer and } \\
\text { payments }\end{array}$ & Borrowing & Insurance \\
\hline $\begin{array}{l}\text { 1. } \begin{array}{l}\text { Peer-to-peer } \\
\text { (marketplace) }\end{array} \\
\text { platforms for } \\
\text { investments }\end{array}$ & $\begin{array}{l}\text { 6. Online Stockbroking or } \\
\text { spread betting }\end{array}$ & $\begin{array}{l}\text { 9. Borrowing using peer-to- } \\
\text { peer platforms }\end{array}$ & $\begin{array}{l}\text { 10. Health premium } \\
\text { aggregators or car } \\
\text { insurance using } \\
\text { telematics intended to } \\
\text { lower premiums }\end{array}$ \\
\hline $\begin{array}{l}\text { 2. Equity or rewards } \\
\text { crowdfunding }\end{array}$ & 7. Overseas remittances & & \\
\hline $\begin{array}{l}\text { 3. Online investment } \\
\text { advice and investment } \\
\text { 4. Online budgeting and } \\
\text { financial planning }\end{array}$ & $\begin{array}{l}\text { 8. Non-banks to transfer } \\
\text { money }\end{array}$ & & \\
\hline $\begin{array}{l}\text { 5. Online Stockbroking or } \\
\text { spread betting }\end{array}$ & & & \\
\hline
\end{tabular}

Source : The journal of Financial Perspective; Fintech, 17- 23. (2015)

There are several ways categorize Fintech [4], indicated that Fintech refers to new solutions which demonstrate an incremental or radical / disruptive innovation development of applications in financial services industry. These solutions was divided into several areas such as; 1) The banking or insurance sector are distinguished as potential business sectors. Solutions for the insurance industry are often more specifically named "InsurTech". 2) The solutions differ with regard to their supported business processes such as financial information, payments (such 
as mobile payment), investments, financing, advisory and cross-process support. 3) The targeted customer segment distinguishes between retail, private and corporate banking as well as life and non-life insurance. 4) The interaction form can either be business-to-business (B2B), businessto-consumer (B2C) or consumer-to-consumer (C2C). 5) The solutions vary with regard to their market position.

Others divide Fintech into several categories such as 1) Savings and investment 2) Money transfer and payment 3) Borrowing and 4) Investment [1] it also revealed that the highest category in Fintech is money transfer and payment.

This research is going to combine several theories to see its connection with the intention to use of Fintech. One of its most common approach is to use TAM (Technology Acceptance Model) in order to see the intention to use of Fintech [6].

Jung [7] has conceptualized that there are several factors that show a significant impact on its satisfaction and attitude in using Fintech. Factors such as self-efficacy, innovativeness, social influence and perceived danger have been proven to have a major impact on user attitude towards using Fintech. Whereas other factors such as social influence and complexity had a significant impact on satisfaction.

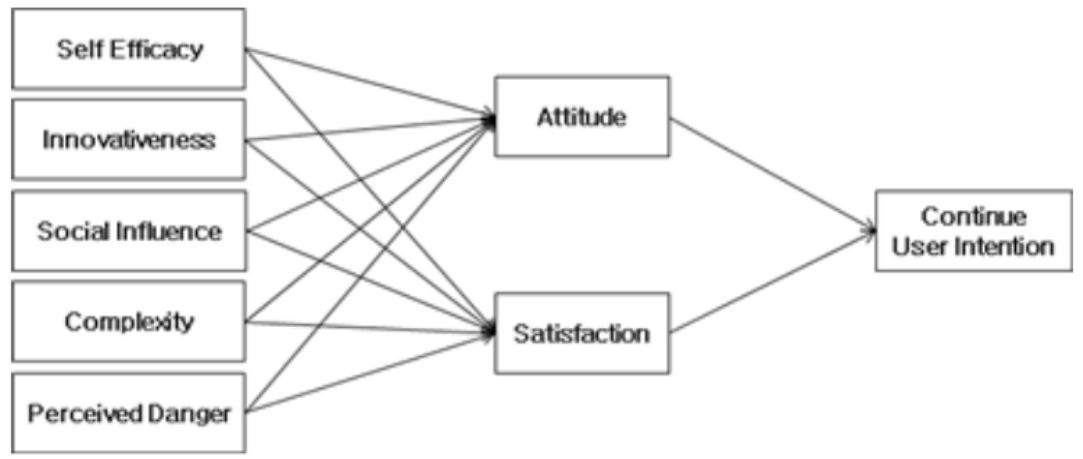

Figure 1. Previous research Model.

Online trust has become an important construct to investigate in the context of e-commerce. Online trust is generally regarded as reliance on a specific firm by its stakeholders with respect to the firm's business activities in the electronic medium generally, through website system or an application (e.g., [8][9]. The trust towards the technology also affecting people attitude and behavior towards the system.

Chuang \& Kao [2] used a different approach in measuring attitude toward using Fintech, they have reached a conclusion that factors such as trust, safety and security is still a major factor that influences attitude. So are factors such as convenience, and finally overall evaluation of users towards the technology that have the biggest impact on their attitude.

Attitude is determined by both perceived usefulness and perceived ease of use. To promote a user's willingness to use a new technology, it is necessary to let potential users believe that the new technology is easy to use and that they can benefit from using it [10]-[12]. 


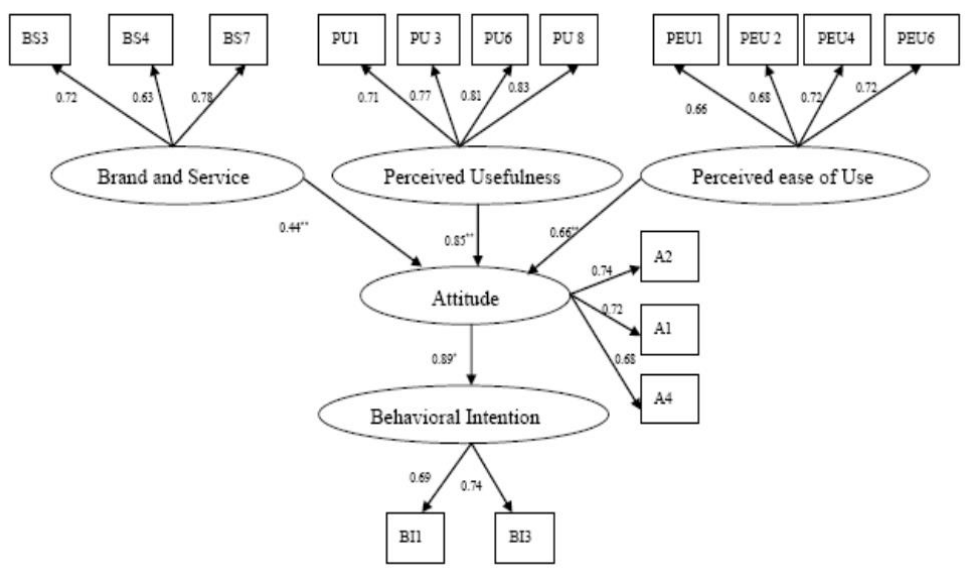

Figure 2. TAM model used in previous research.

Attitude is the positive or negative feelings or evaluations generated when an individual uses new technologies. When a person has a higher positive attitude toward using new technology, the behavioral intention will be comparatively higher. It is determined by both perceived usefulness and perceived ease of use. Attitude toward using refers to a user's assessment of the desirability of using a system or application Ajzen [13], Agarwal and Prasad [14] believe that attitude is a person's affective response to use new technology. Generally, customer satisfaction is viewed as a response based on evaluations and expressed some time during the purchaseconsumption process. Kotler (2000) [15] considered customer satisfaction as a mental state that comes from expectation with the performance perceptions. Previous research in the field of online ticketing also indicating a similar result, that Perceived usefulness, perceived ease of use, and trust all three influence attitudes towards online airlines ticketing usability. Although in several cases, such as in Indonesia, the perceived issues or the trust factor plays an important role that shapes the attitude of Indonesian toward online shopping [16].

\subsection{Perceive usefulness}

The perceived usefulness is "the degree to which a person believes that using a particular system will enhance his or her job performance". On the other hand, when a user believes that the new technology is useful, the user will have a positive attitude toward this new technology. Perceived usefulness is the extent of the belief that using a system or application will help them to perform better [17]. Perceived usefulness is also defined as the degree to which the person believes that using a particular system will enhance their job performance [12]. For TAM framework initially. In TAM framework, PU is hypothesized as the direct predictor of behavioral intention to use (BI) of the technology of interest [18]. Previous studies indicate that PU is associated with continuance intention for electronic messaging [19], [20], instant messaging [21], mobile service provider [22], online travel services [23], e-learning [24] blog learning [25], knowledge creation [26]. 


\subsection{Perceive ease of use}

The perceived ease of use is "the degree to which a person believes that using a new technology is free from effort". When a new technology is perceived by users to be easy to use, and requires less labor and time, then the new technology is more likely to be accepted by users. 2. Behavioral intentions: the degree of a person's willingness to use a new technology. 3. External variables: The factors indirectly affect behaviors, such as the personal variables of users, system characteristics, and environmental variables. Perceived ease of use understood as refers to the degree to which a person believes that using a particular system would be effortless [17], [27] in other words perceived ease of use is the people perception on how easy it is to use an application/system [17], [27]. This theory has been based on the Technology Acceptance Model (TAM) and has been consistently used in scholarly papers focusing on why users choose to utilize a system [12]. In the context the perceive ease of use means how the millennials see the use of Financial Technology is easy and effortless. Previous studies have showed that Perceived ease of Use have association with users continue to use the system or application.

\section{METHOD}

In carrying out this study, this research will add important variable that's often scrutinized in terms of Mobile Payment, Which is Attitude, Behavioral Intention, Perceived usefulness, Perceived ease of Use, Innovativeness, Self-efficacy. To ensure the content validity and reliability of each variable, operationalization and the measurement of these variables is compiled to refer to earlier studies [28]. Furthermore, because of its simplicity, the TAM has become one of the most widely used models in the information systems field [29]. The TAM has been applied to understand user acceptance of internet-based applications and services such as CRM systems, e-mail, web site, online shopping, social networking site Facebook, and so on.

Started with a comprehensive Literature review followed by interview as preliminary research and using quantitative approach in order to achieve good research inference. The research model were shown in research framework

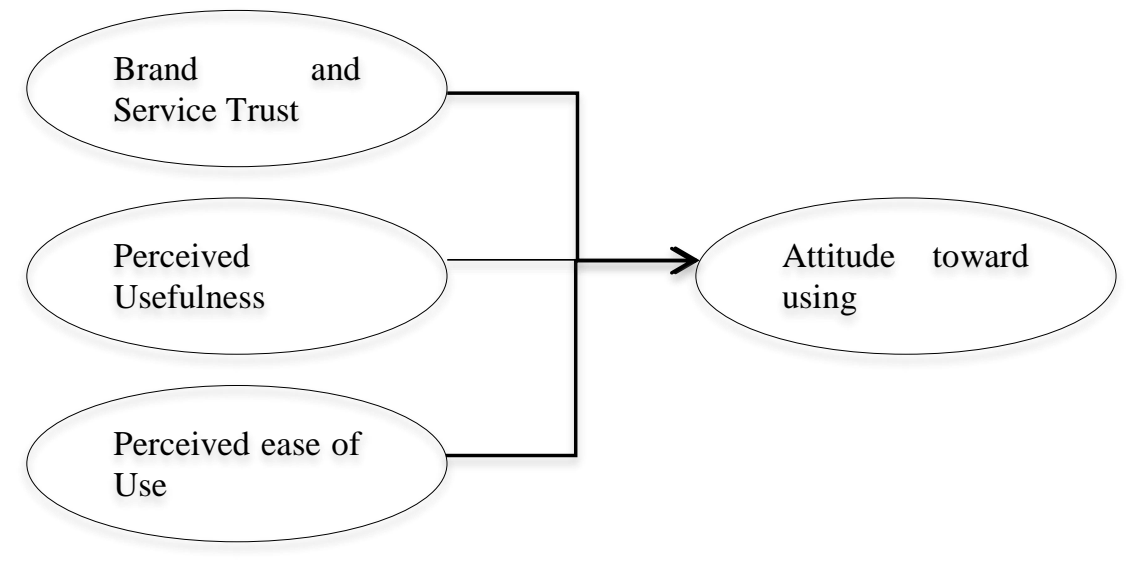

Figure 3. Research Framework 
This research is going to use the variables of Brand and service trust, Perceived usefulness, Perceived ease of use and attitude towards using in order to understand more about the attitude towards fintech service especially for millennials.

Previous study has confirmed that brand is an important of a business and the phenomenon involves the value added to an offering by consumer's perception of and associations with a particular brand name [30]-[32]. Several author also points out that the psychological associations would have an impact for greater market share, and good responses from the consumer in terms of product price [30]-[32].

Trust is the sense of believe and reliability, between people, people to object, organization and brands. The three elements of trust are benevolence, honesty, and competence [33]. According to Singh \& Sirdeshmukh[34] Trust is perceived credibility and benevolence, involves specific beliefs in ability, benevolence, and integrity and is willing to depend on another party

The hypothesis used in this research are:

$\mathrm{H} 1$ : Brand and service trust has a significant positive effect on attitude towards using

$\mathrm{H} 2$ : Perceived usefulness has a significant positive effect on attitude toward using

H3: Perceived ease of use has a significant effect on attitude toward using

\section{RESULT AND DISCUSSION}

The final data collection of this research consists of 70 students filling in questionnaires, there are 14 questions from 4 constructs. The constructs are Brand and service trust (T), perceived usefulness (PU), perceived ease of use (PEOU) and attitude toward using (ATU). The first step in analyzing the data was by running the validity and reliability test. The data analysis used in this research is analyzed using regression analysis and computed using SPSS.

The Cronbach's alpha will represent the reliability of each construct, while the score of sig. and KMO \& Bartlett's test will indicate the validity of the construct and each indicator. Therefore the constructs and indicators used in this research can be used for further analysis. The result of the hypothesis of this research is as shown in table 2. According to the data analysis, it can be concluded that all of the hypothesis on this research is accepted, however, there are several issues that can be observed.

This research confirmed that the issue of trust is one of the significant factors in determining attitude toward using for millennials. Previous research has stated that trust as one of the important factor in terms of fintech use, trust is defined as the perception of stability, security, and safety [35]. Therefore, especially for fintech area it is imperative for companies to build a strong relationship and build a strong image as a trustworthy company.

The usefulness of a technology is a rather interesting topic, several previous researches has pointed out that in terms of system and application, factors of perceived usefulness is one of the most important factors [4][36]. Kim et al has pointed out that perceived usefulness, along with convenience has been an important factors in predicting Fintech adoption. This research has confirmed the hypotheses can be applied for millennials. 
Table 2. Validity and reliability test

\begin{tabular}{|c|c|c|c|c|}
\hline Construct & $\begin{array}{l}\text { Cronbach's } \\
\text { alpha }\end{array}$ & sig. & & \\
\hline Brand \& Service & 0.655 & & Reliable & Valid \\
\hline \multicolumn{5}{|l|}{ Trust (T) } \\
\hline $\mathrm{T} 1$ & & 0.000 & & Valid \\
\hline $\mathrm{T} 2$ & & 0.000 & & Valid \\
\hline T3 & & 0.000 & & Valid \\
\hline $\begin{array}{l}\text { Perceived Usefulness } \\
\text { (PU) }\end{array}$ & 0.674 & & Reliable & Valid \\
\hline PU1 & & 0.000 & & Valid \\
\hline PU2 & & 0.000 & & Valid \\
\hline PU3 & & 0.000 & & Valid \\
\hline PU4 & & 0.000 & & Valid \\
\hline Perceived Ease of & 0.758 & & Reliable & Valid \\
\hline \multicolumn{5}{|l|}{ Use (PEOU) } \\
\hline PEOU1 & & 0.000 & & Valid \\
\hline PEOU2 & & 0.000 & & Valid \\
\hline PEOU3 & & 0.000 & & Valid \\
\hline PEOU4 & & 0.000 & & Valid \\
\hline Attitude & 0.751 & & reliable & Valid \\
\hline \multicolumn{5}{|l|}{ Using (ATU) } \\
\hline ATU1 & & 0.000 & & Valid \\
\hline ATU2 & & 0.000 & & Valid \\
\hline ATU3 & & 0.000 & & Valid \\
\hline
\end{tabular}

Table 3. Hypothesis result

\begin{tabular}{ll}
\hline \multicolumn{1}{c}{ Relationship } & \\
\hline Brand and Service Trust $\rightarrow$ Attitude toward using & Accepted \\
Perceived usefulness $\rightarrow$ Attitude toward using & Accepted \\
Perceived ease of use $\rightarrow$ Attitude toward using & Accepted \\
\hline
\end{tabular}

This research has also confirmed that perceived ease of use as one of the significant factors in determining attitude toward using. Previous literature has point out that perceived ease of use was one of an important factors in designing website for e-commerce [37], a high level of perceived ease of use is important in many ways, for one it helps to navigate easier, it is also one of factor to determine whether a customer will continue to enquiry phase of online purchase, it will also determine of whether or not a consumer will return to the same website to purchase more item, or to do more transaction.

Overall upon conducting this research there are several things that can be concluded from this research. Firstly, even though almost all of the respondents agree that Fintech is very helpful and easy to use security is still the main issue that needs to be addressed by the company. In some way this will also influence how the consumer trusts in using the Financial Technology. Secondly, even though the majority of the respondents are highly involved in technology, their level of use for fintech is still considerably low, they are unwilling to allocate a substantial amount of money into their fintech account, and they tend to be switching from one service to 
another. It indicates that this area still has a lot of potentials to be explored. The switching behavior is one of interesting topics to be explored in future research.

\section{CONCLUSION}

This research has helped to give an illustration of the model of attitude towards using in the context of millennials users and their behavior towards mainstream Financial Technology. This research has confirmed that Brand and service, is indeed still one of the most important factors that influence the millennials toward using FinTech. So is Perceived usefulness is also an important factor that affects someone to use Fintech, because essentially despite the relatively new idea of Fintech, consumers still decide to use Fintech because they feel that it's a very useful feature. Lastly, this research also shown that perceived ease of use is an important determinant that drives people to use Fintech, and this relationship also applied in Millenials context.

\section{REFERENCES}

[1] I. Gulamhuseinwala, T. Bull, and S. Lewis, "FinTech is Gaining Traction and Young, High-Income Users are the Early Adopters," J. Financ. Perspect., vol. 3, no. 3, pp. 1723, 2015.

[2] L.-M. Chuang, C.-C. Liu, and H.-K. Kao, "The Adoption of Fintech Service: TAM perspective," Int. J. Manag. Adm. Sci., vol. 3, no. 7, pp. 1-15, 2015.

[3] H. Ali and L. Purwandi, Indonesia 2020: The Urban Middle Class Millennials. Jakarta: PT Alvara Strategi Indonesia, 2016.

[4] Y. Kim, Y. J. Park, J. Choi, and Y. J, "The Adoption of Mobile Payment Services for 'Fintech ,"' Int. J. Appl. Eng. Res., vol. 11, no. 2, pp. 1058-1061, 2016.

[5] M. E. Porter and M. R. Kramer, "Creating Shared Value," in Managing Sustainable Business, Dordrecht: Springer Netherlands, 2019, pp. 323-346.

[6] D. Folkinshteyn and M. Lennon, "Braving Bitcoin: A technology acceptance model (TAM) analysis," J. Inf. Technol. Case Appl. Res., vol. 18, no. 4, pp. 220-249, Oct. 2016.

[7] L.-S. Jung, "The Relationship between Attitude and Satisfaction for Improving Continue User Intention in Fintech," Int. J. IT Bus. Strateg. Manag., vol. 2, no. 1, pp. 29-34, Dec. 2016.

[8] D. J. Kim, "An investigation of the effect of online consumer trust on expectation, satisfaction, and post-expectation," Inf. Syst. E-bus. Manag., vol. 10, no. 2, pp. 219-240, Jun. 2012.

[9] V. Shankar, G. L. Urban, and F. Sultan, "Online trust: a stakeholder perspective, concepts, implications, and future directions," J. Strateg. Inf. Syst., vol. 11, no. 3-4, pp. 325-344, Dec. 2002.

[10] Y. A. Au and R. J. Kauffman, "The economics of mobile payments: Understanding stakeholder issues for an emerging financial technology application," Electron. Commer. Res. Appl., vol. 7, no. 2, pp. 141-164, Jun. 2008.

[11] J. V. Duca, "Financial Technology Shocks and the Case of the Missing M2," J. Money, Credit Bank., vol. 32, no. 4, pp. 820-839, 2000.

[12] F. D. Davis, "Perceived Usefulness, Perceived Ease of Use, and User Acceptance of Information Technology," MIS Q., vol. 13, no. 3, pp. 319-340, 1989.

[13] I. Ajzen and M. Fishbein, Understanding Attitudes and Predicting Social Behavior. 
Upper Saddle River, NJ: Prentice-Hall, 1980.

[14] R. Agarwal and J. Prasad, "A Conceptual and Operational Definition of Personal Innovativeness in the Domain of Information Technology," Inf. Syst. Res., vol. 9, no. 2, pp. 204-215, Jun. 1998.

[15] P. Kotler and K. L. Keller, Marketing Management. New Jersey: Prentice Hall, 2012.

[16] Renny, S. Guritno, and H. Siringoringo, "Perceived Usefulness, Ease of Use, and Attitude Towards Online Shopping Usefulness Towards Online Airlines Ticket Purchase," Procedia - Soc. Behav. Sci., vol. 81, pp. 212-216, Jun. 2013.

[17] J. Zhou, "Exploring the factors affecting learners' continuance intention of MOOCs for online collaborative learning: An extended ECM perspective," Australas. J. Educ. Technol., vol. 33, no. 5, pp. 123-135, Apr. 2017.

[18] N. Park, M. Rhoads, J. Hou, and K. M. Lee, "Understanding the acceptance of teleconferencing systems among employees: An extension of the technology acceptance model," Comput. Human Behav., vol. 39, pp. 118-127, Oct. 2014.

[19] L. Baker-Eveleth and R. W. Stone, "Usability, expectation, confirmation, and continuance intentions to use electronic textbooks," Behav. Inf. Technol., vol. 34, no. 10, pp. 992-1004, Oct. 2015.

[20] R. W. Stone and L. Baker-Eveleth, "Students' expectation, confirmation, and continuance intention to use electronic textbooks," Comput. Human Behav., vol. 29, no. 3, pp. 984-990, May 2013.

[21] W. Wang, E. W. T. Ngai, and H. Wei, "Explaining Instant Messaging Continuance Intention: The Role of Personality," Int. J. Hum. Comput. Interact., vol. 28, no. 8, pp. 500-510, Aug. 2012.

[22] H. A. Abbas and H. I. Hamdy, "Determinants of continuance intention factor in Kuwait communication market: Case study of Zain-Kuwait," Comput. Human Behav., vol. 49, pp. 648-657, Aug. 2015.

[23] H. Li and Y. Liu, "Understanding post-adoption behaviors of e-service users in the context of online travel services," Inf. Manag., vol. 51, no. 8, pp. 1043-1052, Dec. 2014.

[24] W.-S. Lin and C.-H. Wang, "Antecedences to continued intentions of adopting elearning system in blended learning instruction: A contingency framework based on models of information system success and task-technology fit," Comput. Educ., vol. 58, no. 1, pp. 88-99, Jan. 2012.

[25] J. E. Tang, T.-I. Tang, and C.-H. Chiang, "Blog learning: effects of users' usefulness and efficiency towards continuance intention," Behav. Inf. Technol., vol. 33, no. 1, pp. 36-50, Jan. 2014.

[26] S.-W. Chou, H.-T. Min, Y.-C. Chang, and C.-T. Lin, "Understanding continuance intention of knowledge creation using extended expectation-confirmation theory: an empirical study of Taiwan and China online communities," Behav. Inf. Technol., vol. 29, no. 6, pp. 557-570, Nov. 2010.

[27] E. Karahanna and D. W. Straub, "The psychological origins of perceived usefulness and ease-of-use,” Inf. Manag., vol. 35, no. 4, pp. 237-250, Apr. 1999.

[28] U. Sekaran and R. Bougie, Research methods for business. UK: John Wiley and Sons, 2016.

[29] W. R. King and J. He, "A meta-analysis of the technology acceptance model," Inf. Manag., vol. 43, no. 6, pp. 740-755, Sep. 2006.

[30] A. Chaudhuri and M. B. Holbrook, "The Chain of Effects from Brand Trust and Brand Affect to Brand Performance: The Role of Brand Loyalty," J. Mark., vol. 65, no. 2, pp. 81-93, Apr. 2001. 
[31] D. A. Aaker, "Measuring Brand Equity Across Products and Markets," Calif. Manage. Rev., vol. 38, no. 3, pp. 102-120, Apr. 1996.

[32] A. L. Baldinger and J. Rubinson, "Brand loyalty: the link between attitude and behavior," J. Advert. Res., vol. 36, no. 6, pp. 22-35, 1996.

[33] P. M. Doney and J. P. Cannon, "An Examination of the Nature of Trust in Buyer-Seller Relationships,” J. Mark., vol. 61, no. 2, pp. 35-51, Apr. 1997.

[34] J. Singh and D. Sirdeshmukh, "Agency and Trust Mechanisms in Consumer Satisfaction and Loyalty Judgments," J. Acad. Mark. Sci., vol. 28, no. 1, pp. 150-167, Jan. 2000.

[35] K. Riemer et al., The Fintech Advantage: Harnessing digital technology, keeping the customer in focus. Sydney: University of Sydney, Business School and Capgemini, 2017.

[36] A. Dickinger, M. Arami, and D. Meyer, "Reconsidering the Adoption Process: Enjoyment and Social Norms \&amp;\#8212; Antecedents of Hedonic Mobile Technology Use," in Proceedings of the 39th Annual Hawaii International Conference on System Sciences (HICSS'06), 2006, p. 23a-23a.

[37] H.-M. Kuo and C.-W. Chen, "Application of quality function deployment to improve the quality of Internet shopping website interface design," Int. J. Innov. Comput. Inf. Control, vol. 7, no. 1, pp. 253-268, 2011. 